\title{
SHELF LIFE AND QUALITY OF BOLOGNA-TYPE FAT REDUCED TURKEY SAUSAGE
}

\author{
É. Varga-Visi*, B. Toxanbayeva, G. Andrássyné BaKa and R. Romvári \\ Faculty of Agriculture and Environmental Sciences, Kaposvár University H-7400 Kaposvár, Guba S. u. 40., \\ Hungary
}

(Received: 24 May 2019; accepted 21 August 2019)

\begin{abstract}
This study aimed to evaluate the effect of refrigerated storage on the microbial properties and organoleptic quality of Bologna-type turkey sausage, in which fat was partially replaced with pea fibre or potato starch. Each manufactured sausage had lower counts of Esherichia coli and enterobacteria than $1 \log \mathrm{CFU} \cdot \mathrm{g}^{-1}$, counts were below 2 log $\mathrm{CFU} \cdot \mathrm{g}^{-1}$ for Staphylococcus aureus, moreover, no Salmonella spp. were found in any of the sausages. The counts of mesophilic aerobic bacteria did not exceed $4 \log \mathrm{CFU} \cdot \mathrm{g}^{-1}$ for each sausage formulation during four-week storage at $4{ }^{\circ} \mathrm{C}$. Spectrocolorimetric measurements revealed that there was no decline in luminosity (L*) and redness (a*) by time, namely colour fading did not occur. Saltiness and juiciness values of sausages were directly proportional. Lowfat sausages were perceived less salty than full-fat analogue with the same salt content at the early stage of storage. Nevertheless, this phenomenon was temporary as sausages had the same saltiness at the end of four-week storage period. Sausages, in which $25 \%$ of fat was substituted with pea fibre or potato starch, were assessed as having the same odour, consistency, taste, and overall impact like control during the four-week refrigerated storage.
\end{abstract}

Keywords: meat product, fat substitutes, sensory properties, microbial stability, pea fibre, potato starch

High fat intake is associated with many chronic health conditions, i.e. cardiovascular diseases. Health concerns related to processed meat products led to the development of their low-fat analogs. In the case of comminuted meat products, fat can be entirely or partially replaced with carbohydrates and/or proteins to reduce energy density. Low-fat products can be accepted by consumers if they have similar organoleptic properties as conventional products. Many fat replacers proved to be successful in reaching the aim as it has been reviewed previously (VARGA-VisI \& ToXANBAYEVA, 2017). However, most papers referred to observations on fresh products and did not report the effect of storage on quality. The decrease of shelf life can be a possible situation for low-fat meat products as fat substitution leads to increase of water content (NowAK et al., 2007).

Pea fibre and potato starch have been used to produce low-fat Bologna sausages and their textural and organoleptic properties have been evaluated related to full-fat control (VARGA-VISI et al., 2017; 2018). Nevertheless, these studies were conducted on freshly prepared sausages. The present study aimed to evaluate the effect of refrigerated storage on the microbiological and organoleptic properties of low-fat analogs related to full-fat control.

\section{Materials and methods}

Sausages with different formulation were processed in a pilot plant at Kaposvár University as described elsewhere (VARGA-VISI et al., 2018). In the experimental sausages, the ratio of fat

\footnotetext{
* To whom correspondence should be addressed.

Phone: +36 82505 800/2307; fax: +36 82321 749; e-mail: vargane.eva@ke.hu
}

0139-3006 (C) 2020 The Authors 
was reduced by approximately 25,50 , and $75 \%$ compared to the full-fat reference product. Ratios of lean meat, spice mixture, and salt were kept constant for each type of sausage (Table 1).

Table 1. Composition of ingredients used for processing Bologna-type turkey sausages

\begin{tabular}{|c|c|c|c|c|c|c|c|}
\hline \multirow{2}{*}{$\begin{array}{l}\text { Ingredients } \\
(\mathrm{w} / \mathrm{w}) \%\end{array}$} & \multirow[t]{2}{*}{ Control } & \multicolumn{6}{|c|}{ Low-fat products ${ }^{1}$} \\
\hline & & $\mathrm{S} 1$ & $\mathrm{~S} 2$ & S3 & $\mathrm{F} 1$ & $\mathrm{~F} 2$ & F3 \\
\hline Turkey meat & 58.3 & 58.3 & 58.3 & 58.3 & 58.3 & 58.3 & 58.3 \\
\hline Shredded ice & 19.4 & 19.4 & 19.4 & 19.4 & 19.4 & 19.4 & 19.4 \\
\hline Goose fat & 19.4 & 14.6 & 9.7 & 4.9 & 14.6 & 9.7 & 4.9 \\
\hline Starch (potato) & - & 1.94 & 3.88 & 5.83 & - & - & - \\
\hline Water supplement $^{2}$ & - & 2.91 & 5.83 & 8.74 & 4.27 & 8.54 & 12.82 \\
\hline Fibre (pea) & - & - & - & - & 0.58 & 1.17 & 1.75 \\
\hline Spice mixture $^{3}$ & 0.97 & 0.97 & 0.97 & 0.97 & 0.97 & 0.97 & 0.97 \\
\hline Salt with nitrite ${ }^{4}$ & 1.94 & 1.94 & 1.94 & 1.94 & 1.94 & 1.94 & 1.94 \\
\hline
\end{tabular}

1: S: potato starch; F: pea fibre; 1: $25 \%$ of fat was substituted; $2: 50 \%$ of fat was substituted; $3: 75 \%$ of fat was substituted.

2: Water supplement was applied to low fat products in the form of shredded ice.

3: Bologna sausage type spice mixture contained diphosphate and sodium-iso-ascorbic acid.

4. Salt with nitrite consisted of $0.45 \pm 0.05(\mathrm{w} / \mathrm{w}) \%$ sodium nitrite.

Three repetitions were performed for each formulation on three different days. Sausages were stored at $4 \pm 2{ }^{\circ} \mathrm{C}$ in dark for four weeks. Microbiological assays, $\mathrm{pH}$ and instrumental colour measurements, and sensory analyses were conducted weekly. The colony forming unit (CFU) number of Escherichia coli, Staphylococcus aureus, Salmonella spp., Enterobacteriaceae, and CFU of the total number of bacteria were determined according to the following standards: MSZ ISO 16649-2:2005, EN ISO 6888-1:2008, EN ISO 6579:2006, MSZ ISO 21528-2:2007, and EN ISO 4833:2003, respectively. The test used for the determination of total cell count (EN ISO 4833:2003) detects the growth of mesophilic bacteria under aerobic conditions and can be used for all food commodities except fermented foods.

Instrumental colour parameters were measured, and organoleptic assays were accomplished as described elsewhere (VARGA-VISI et al., 2017); pH values were measured with a Testo $205 \mathrm{pH}$ meter. For colour values and $\mathrm{pH}$, each elemental sample was measured four times. Panellists scored colour, odour, consistency, taste, and overall acceptability on a nine-point hedonic scale from one (extreme dislike) to nine (like extremely). Assessors also evaluated the next sensory descriptors of the samples: saltiness (1: unsalted, 9: too salty) and juiciness (1: very dry, 9: very juicy).

Comparison of treatment means was evaluated with analysis of variance. StudentNewman-Keuls post hoc test was used if variances were homogeneous among groups; in the opposite case, Tamhane's test was applied. Kruskal-Wallis nonparametric test was used when variables did not follow a normal distribution. Calculations were performed using a commercial statistical software package (IBM SPSS Statistics 20). 


\section{Results and discussion}

Each manufactured sausage had lower counts of Esherichia coli and enterobacteria than $1 \log$ CFU $\cdot \mathrm{g}^{-1}$, and counts were below $2 \log \mathrm{CFU} \cdot \mathrm{g}^{-1}$ for Staphylococcus aureus during storage. In the present work, no Salmonella spp. were found in any of the treatments. Inclusion of fat replacers (starch or pea fibre) and water supplement (Table 1) in the formulation did not promote the growth of these bacteria.

The counts of mesophilic aerobic bacteria did not exceed $4 \log \mathrm{CFU} \cdot \mathrm{g}^{-1}$ for each sausage formulation during four-week chilled storage. The total bacterial count tended to decrease in sausages between the first and the third weeks of storage (Fig. 1), followed by a moderate increase on the fourth week. DE ALMEIDA and co-workers (2015) observed consistent growth of these bacteria when commercial Bologna sausage was chilled stored, while others (COLMENERo et al., 1996; VIUDA-MARTOS et al., 2010) detected little change at the early stage of storage. In an early study, when fat was replaced per se with water, without the addition of hydrocolloids, higher cell counts were detected for low-fat sausages than for full-fat control, presumably owing to the higher unbound water content in reduced fat samples (COLMENERo et al., 1996). Application of fat replacers can overcome this problem as it was reported for inulin (NOwAK et al., 2007) and in the present assay for pea fibre and potato starch.

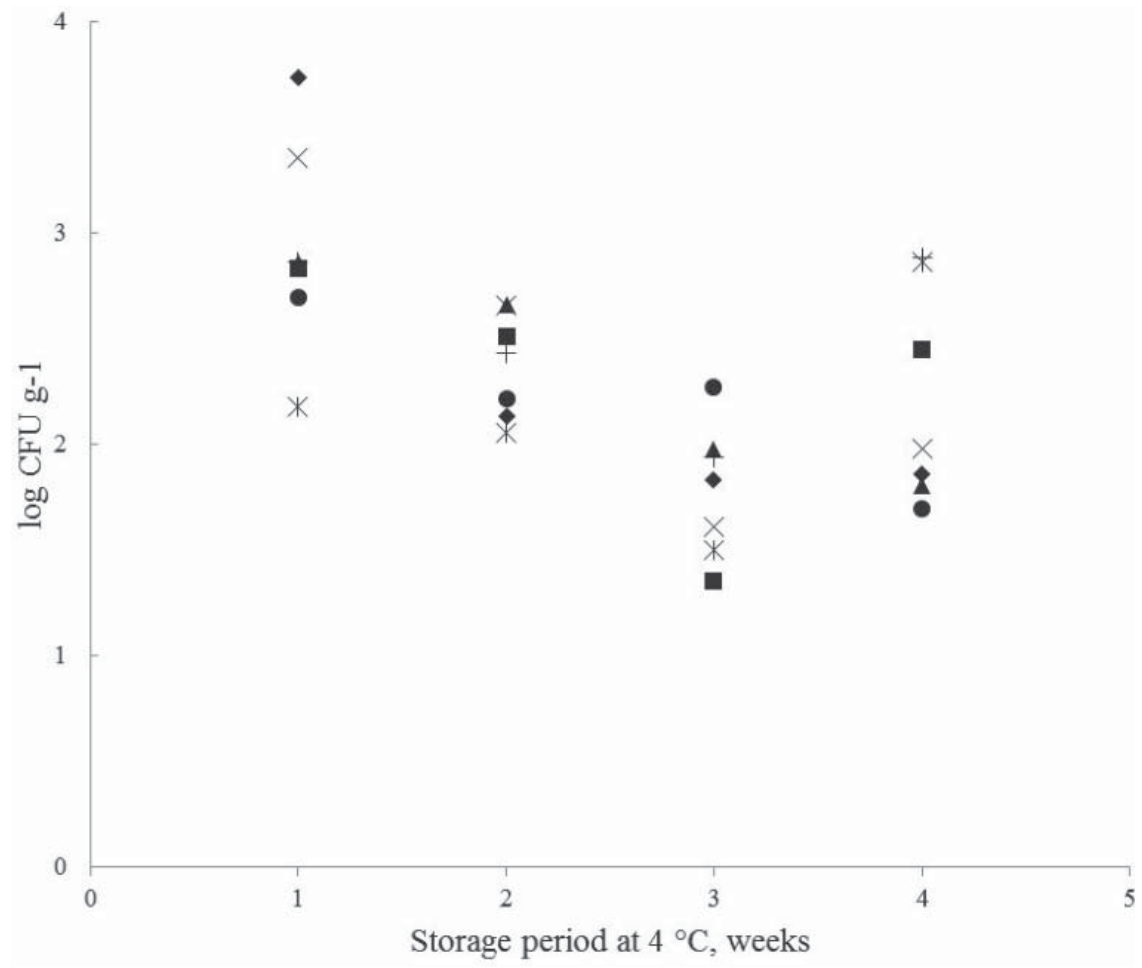

Fig. 1. Total aerob microbial counts of Bologna-type turkey sausages stored at $4{ }^{\circ} \mathrm{C}$.

S: potato starch; F: pea fibre; $1: 25 \%$ of fat was substituted; $2: 50 \%$ of fat was substituted; $3: 75 \%$ of fat was substituted.

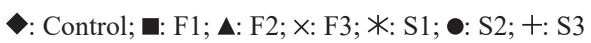


The $\mathrm{pH}$ values of the sausage samples decreased during the storage (Table 2). The differences by time were significant between the values of the second and the third weeks of storage. Others also measured some decline in $\mathrm{pH}$ during chilled storage of Bologna sausage at the same magnitude (Holley, 1997; Feng et al., 2013; DE Almeida et al., 2015). The tendency of $\mathrm{pH}$ decrease was similar among sausages with different formulations. On the third week, the control product had significantly higher $\mathrm{pH}$ value than fat replaced sausages, but there were no significant differences at the end of the storage, on the fourth week. NowAK and co-workers (2007), with the use of inulin, observed higher $\mathrm{pH}$ value of control compared to low-fat sausages at the end of the 23-day refrigerated storage period. In that case, the difference between the $\mathrm{pH}$ of control product and low-fat sausages might be attributed to the presence of more available fermentable carbohydrates in low-fat sausages. Chilled storage of Bologna sausage promotes the growth of lactic acid bacteria, which can cause spoilage (Holley, 1997, Viuda-Martos et al., 2010), and inulin might act as prebiotic for some strains of these bacteria. However, in our experiment, the effect of time on $\mathrm{pH}$ was greater than the effect of formulation (Table 2). Time dependent $\mathrm{pH}$ decrease did exist for all types of samples, including control product, while composition exerted only a minor effect on $\mathrm{pH}$.

Table 2. The effect of refrigerated storage on $\mathrm{pH}$ of Bologna-type turkey sausages

\begin{tabular}{|c|c|c|c|c|}
\hline \multirow[t]{2}{*}{ Type } & \multicolumn{4}{|c|}{ Storage period at $4{ }^{\circ} \mathrm{C}$, weeks } \\
\hline & 1 & 2 & 3 & 4 \\
\hline Control & $6.78 \pm 0.07^{\mathrm{b}, \mathrm{AB}}$ & $6.68 \pm 0.14^{\mathrm{b}, \mathrm{A}}$ & $6.51 \pm 0.02^{\mathrm{a}, \mathrm{C}}$ & $6.49 \pm 0.04^{\mathrm{a}, \mathrm{A}}$ \\
\hline $\mathrm{S} 1$ & $6.77 \pm 0.04^{\mathrm{b}, \mathrm{B}}$ & $6.69 \pm 0.11^{\mathrm{b}, \mathrm{A}}$ & $6.47 \pm 0.01^{\mathrm{a}, \mathrm{B}}$ & $6.48 \pm 0.04^{\mathrm{a}, \mathrm{A}}$ \\
\hline S2 & $6.72 \pm 0.06^{\mathrm{b}, \mathrm{AB}}$ & $6.64 \pm 0.14^{\mathrm{b}, \mathrm{A}}$ & $6.44 \pm 0.02^{\mathrm{a}, \mathrm{A}}$ & $6.45 \pm 0.04^{\mathrm{a}, \mathrm{A}}$ \\
\hline S3 & $6.74 \pm 0.04^{\mathrm{b}, \mathrm{AB}}$ & $6.62 \pm 0.13^{\mathrm{b}, \mathrm{A}}$ & $6.44 \pm 0.02^{\mathrm{a}, \mathrm{A}}$ & $6.45 \pm 0.03^{\mathrm{a}, \mathrm{A}}$ \\
\hline F1 & $6.75 \pm 0.05^{\mathrm{c}, \mathrm{AB}}$ & $6.63 \pm 0.11^{\mathrm{b}, \mathrm{A}}$ & $6.45 \pm 0.03^{\mathrm{a}, \mathrm{AB}}$ & $6.46 \pm 0.04^{\mathrm{a}, \mathrm{A}}$ \\
\hline $\mathrm{F} 2$ & $6.74 \pm 0.05^{\mathrm{b}, \mathrm{AB}}$ & $6.64 \pm 0.15^{\mathrm{b}, \mathrm{A}}$ & $6.47 \pm 0.04^{\mathrm{a}, \mathrm{AB}}$ & $6.46 \pm 0.01^{\mathrm{a}, \mathrm{A}}$ \\
\hline F3 & $6.71 \pm 0.02^{\mathrm{b}, \mathrm{A}}$ & $6.62 \pm 0.13^{\mathrm{b}, \mathrm{A}}$ & $6.45 \pm 0.02^{\mathrm{a}, \mathrm{AB}}$ & $6.45 \pm 0.03^{\mathrm{a}, \mathrm{A}}$ \\
\hline
\end{tabular}

Means within row with different lowercase superscript letters are significantly different $(\mathrm{P}<0.05)$.

Means within column with different capital superscript letters are significantly different $(\mathrm{P}<0.05)$.

Values are mean \pm standard deviation $(\mathrm{n}=12)$.

S: potato starch; F: pea fibre; 1: $25 \%$ of fat was substituted; $2: 50 \%$ of fat was substituted; $3: 75 \%$ of fat was substituted.

The formation of colour and its stability are essential quality characteristics of cooked meat products (VIUDA-MarTos et al., 2010). Consumers prefer bright and pink colour products. Bright colour is associated with lightness ( $\left.\mathrm{L}^{*}\right)$. During refrigerated storage, colour fading can occur, which strongly associates with the decrease in the colour coordinate $a^{*}$ positive (redness) (JimÉneZ-Colmenero \& CASSEns, 1987; NowAK et al., 2007). In our work neither $\mathrm{a}^{*}$ nor $\mathrm{L}^{*}$ values decreased during storage, namely there was no loss of red colour and brightness. In the experiment of CÁCERES and co-workers (2008), the colour coordinates of Bologna-type sausages with pre-emulsified fish oil were constant for 90 days of refrigerated storage. However, DE ALMEIDA and co-workers (2015) detected a decrease in redness after 35 days for commercial sausage, which could be prevented with the addition of jaboticaba peel 
extract. Substantial colour fading was detected when sliced sausages were stored in illuminated chambers under supermarket retail conditions for 24 days (VIUDA-MARTOS et al., 2010). Contrary, in the present study, for sausages not exposed to light and stored in casings, no colour fading was observed.

Formulation affected colour coordinates. Sausages with pea fibre, i.e. F1, F2, and F3, had significantly higher $L^{*}$ values $(77.01,77.02$, and 76.79 , respectively, mean values for the whole storage period) than sausages formulated with potato starch, i.e. S1, S2, and S3 (74.61, 75.08 , and 73.98 , respectively). The means of redness ( $\mathrm{a}^{*}$ value) were significantly higher in samples with starch $(12.34,12.49$, and 12.34$)$ than in samples with fibre $(11.80,11.59$, and 11.73). Namely, at the same level of fat substitution, pea fibre resulted in lighter sausage, while replacement of fat with starch caused redder sausage. These results were in accordance with a preliminary assay, when fresh sausage samples with the same formulations were compared (VARGA-VISI et al., 2017).

The average scores of different sausages regarding colour, odour, consistency, taste, and overall impact, for the most part, exceeded the value of five, i.e. most products belonged to the upper part of the range between one and nine (Fig. 2). NowAK and co-workers reported (2007) that refrigerated storage of Bologna-type sausage with inulin fat replacer had only minor effect on the sensory quality. In the present work, low-fat products with $25 \%$ of fat substitution, i.e. S1 and F1, were assessed as having the same quality regarding colour, odour, consistency, taste, and overall impact during refrigerated storage. Nevertheless, in the case of sausages, in which higher ratio of fat (50 and $75 \%$ ) was replaced with fibre or starch, some decline was detected in the sensory characteristics.

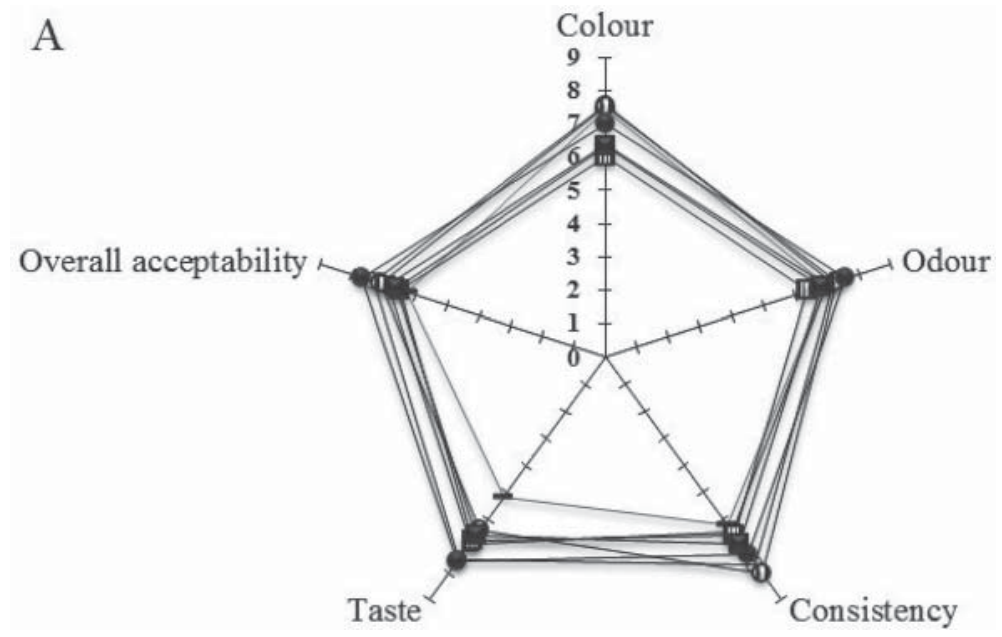

Fig. 2. Average scores of sensorial analysis of Bologna-type turkey sausages stored at $4{ }^{\circ} \mathrm{C}$ for two weeks (a), three weeks (b), and four weeks (c). S: potato starch; F: pea fibre; 1: 25\% of fat was substituted; $2: 50 \%$ of fat was substituted; $3: 75 \%$ of fat was substituted.

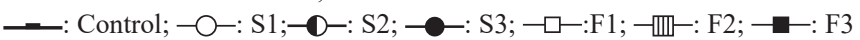



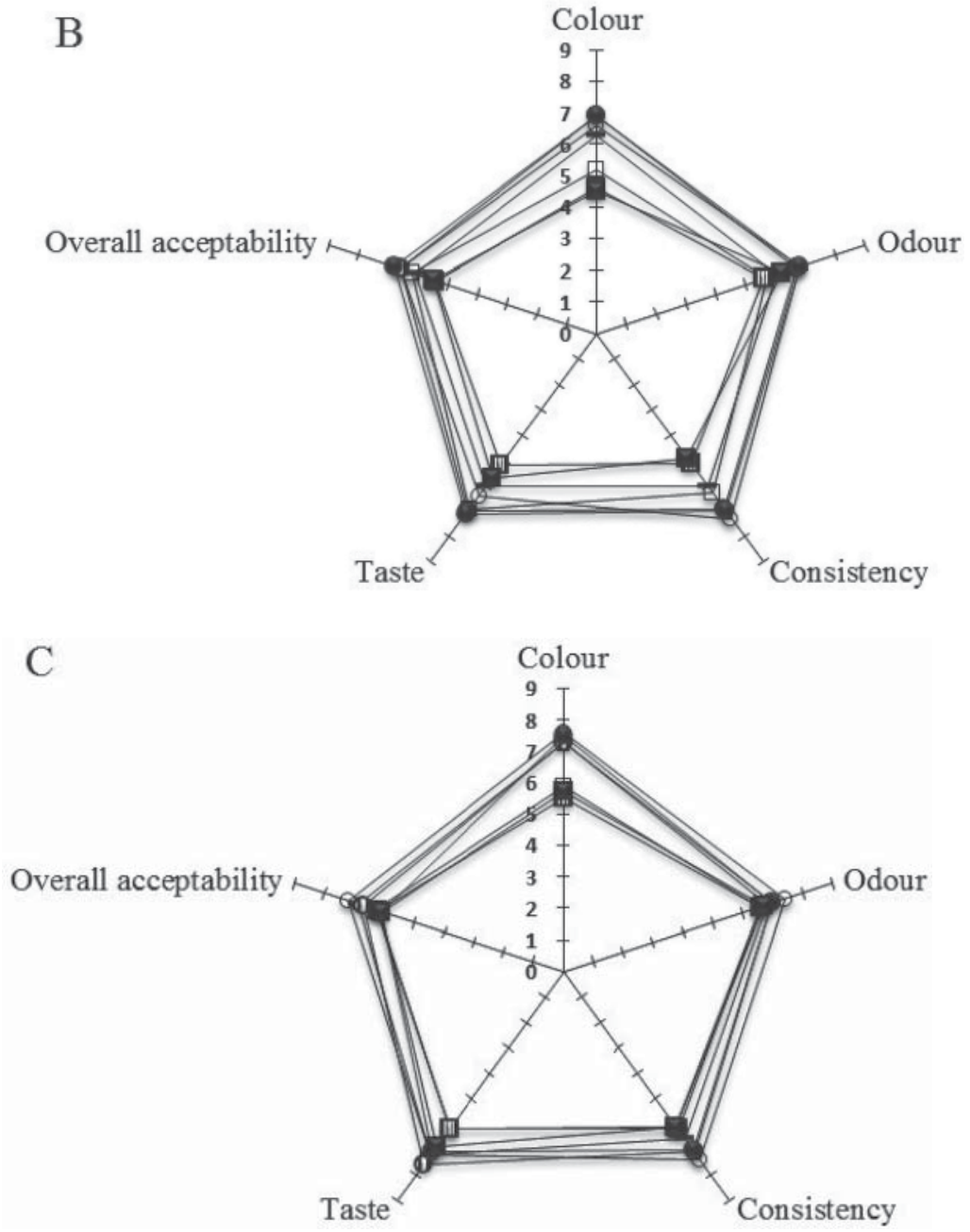

Fig. 2.Continued

Evaluating the effect of formulation, it was observed that samples with potato starch, i.e. $\mathrm{S} 1, \mathrm{~S} 2$, and S3 were assessed as having more accepted colours (7.2, 7.2, and 7.1, respectively, mean values for the whole storage period) than those with pea fibre, i.e. F1, F2, and F3 (5.9, 5.3, and 5.9 respectively). The instrumental colour assay showed that the advantage of starch over fibre was to increase the redness ( $\left.\mathrm{a}^{*}\right)$ values, while the advantage of fibre over starch was to give higher luminosity $\left(\mathrm{L}^{*}\right)$ to sausages. In the organoleptic assay, starch was preferred to fibre, which might mean that in this case redness had a greater effect on the visual evaluation than lightness.

The taste of control product improved in course of time (Fig. 2). This observation may be associated with the changes in saltiness. Control sausage was regarded as too salty on the 
second week as the mean score obtained for saltiness was 7.6 (Table 3). Score 5 would mean neither too salty nor unsalted. However, assessors detected a significant decrease in the saltiness by time (Table 3 ). Since it was too salty at the beginning of storage, its taste also improved by time. Contrary to the control product, panellists did not detect significant changes in saltiness in any types of low-fat sausages in the function of time (Table 3).

Saltiness was directly proportional to juiciness (Fig. 3). The decrease of saltiness can be associated with that of juiciness. If the sausage is less juicy, less liquid having salt in solution is released during mastication, therefore assessors perceive it less salty. Parallel to the decrease of saltiness, the juiciness of the control also decreased by time, from the second to the fourth week of storage (Table 3 ).

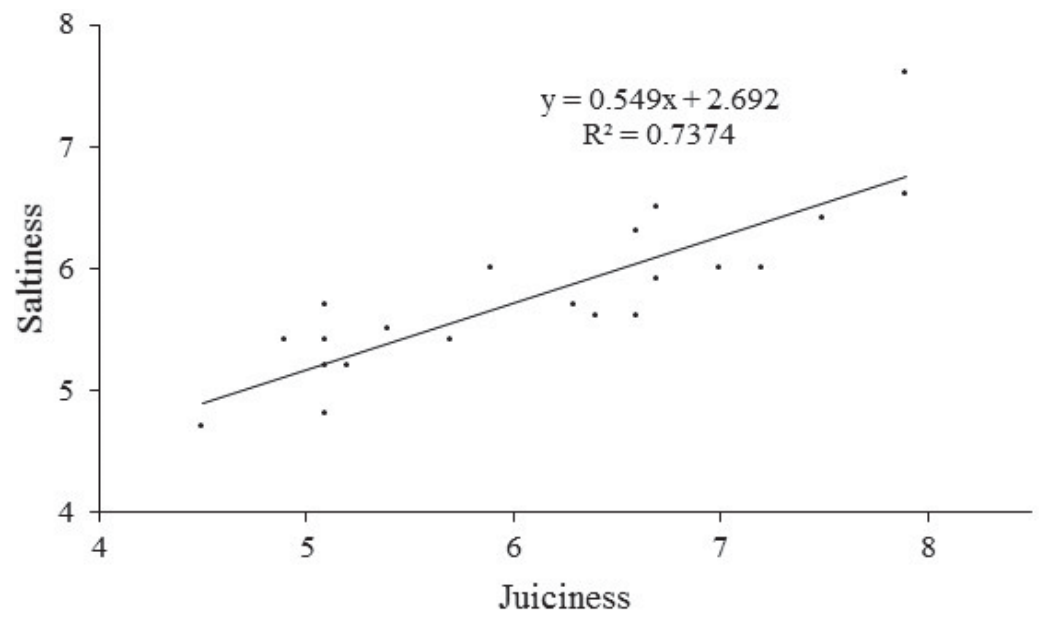

Fig. 3. Correlation between saltiness and juiciness. Values were obtained from Table 3. (Bologna-type turkey sausages with different formulations and storage time periods at $4{ }^{\circ} \mathrm{C}$.)

Each point represents a mean value $(n=11)$ obtained from experimental units having the same formulation and storage time.

Table 3. Sensory scores of saltiness and juiciness of chilled stored Bologna-type turkey sausages

\begin{tabular}{|c|c|c|c|c|c|c|}
\hline \multirow[t]{3}{*}{ Type } & \multicolumn{3}{|c|}{ Saltiness } & \multicolumn{3}{|c|}{ Juiciness } \\
\hline & \multicolumn{3}{|c|}{ Storage period at $4{ }^{\circ} \mathrm{C}$, weeks } & \multicolumn{3}{|c|}{ Storage period at $4{ }^{\circ} \mathrm{C}$, weeks } \\
\hline & 2 & 3 & 4 & 2 & 3 & 4 \\
\hline Control & $7.6 \pm 1.4^{\mathrm{b}, \mathrm{B}}$ & $6.3 \pm 1.2^{\mathrm{a}, \mathrm{B}}$ & $6.0 \pm 0.9^{\mathrm{a}, \mathrm{A}}$ & $7.4 \pm 2.4^{\mathrm{b}, \mathrm{B}}$ & $6.1 \pm 0.8^{\mathrm{ab}, \mathrm{B}}$ & $5.4 \pm 1.1^{\mathrm{a}, \mathrm{AB}}$ \\
\hline S1 & $5.7 \pm 1.1^{\mathrm{a}, \mathrm{A}}$ & $5.4 \pm 1.2^{\mathrm{a}, \mathrm{AB}}$ & $5.2 \pm 1.1^{\mathrm{a}, \mathrm{A}}$ & $4.6 \pm 1.7^{\mathrm{a}, \mathrm{A}}$ & $4.4 \pm 1.4^{\mathrm{a}, \mathrm{A}}$ & $4.6 \pm 0.9^{\mathrm{a}, \mathrm{A}}$ \\
\hline $\mathrm{S} 2$ & $5.5 \pm 1.7^{\mathrm{a}, \mathrm{A}}$ & $5.4 \pm 0.7^{\mathrm{a}, \mathrm{AB}}$ & $5.4 \pm 1.3^{\mathrm{a}, \mathrm{A}}$ & $4.9 \pm 2.2^{\mathrm{a}, \mathrm{A}}$ & $4.6 \pm 0.8^{\mathrm{a}, \mathrm{A}}$ & $5.2 \pm 1.8^{\mathrm{a}, \mathrm{A}}$ \\
\hline S3 & $5.2 \pm 0.6^{\mathrm{a}, \mathrm{A}}$ & $4.7 \pm 1.2^{\mathrm{a}, \mathrm{A}}$ & $4.8 \pm 1.9^{\mathrm{a}, \mathrm{A}}$ & $4.7 \pm 1.3^{\mathrm{a}, \mathrm{A}}$ & $4.0 \pm 1.2^{\mathrm{a}, \mathrm{A}}$ & $4.6 \pm 2.0^{\mathrm{a}, \mathrm{A}}$ \\
\hline F1 & $5.7 \pm 1.3^{\mathrm{a}, \mathrm{A}}$ & $6.0 \pm 1.3^{\mathrm{a}, \mathrm{B}}$ & $5.6 \pm 1.4^{\mathrm{a}, \mathrm{A}}$ & $5.8 \pm 1.7^{\mathrm{a}, \mathrm{AB}}$ & $6.7 \pm 1.1^{\mathrm{a}, \mathrm{BC}}$ & $5.9 \pm 1.3^{\mathrm{a}, \mathrm{AB}}$ \\
\hline F2 & $5.6 \pm 1.4^{\mathrm{a}, \mathrm{A}}$ & $6.5 \pm 0.9^{\mathrm{a}, \mathrm{B}}$ & $5.9 \pm 1.5^{\mathrm{a}, \mathrm{A}}$ & $6.1 \pm 1.8^{\mathrm{a}, \mathrm{AB}}$ & $6.2 \pm 1.2^{\mathrm{a}, \mathrm{B}}$ & $6.2 \pm 1.5^{\mathrm{a}, \mathrm{AB}}$ \\
\hline F3 & $6.0 \pm 1.2^{\mathrm{a}, \mathrm{A}}$ & $6.6 \pm 1.1^{\mathrm{a}, \mathrm{B}}$ & $6.4 \pm 1.5^{\mathrm{a}, \mathrm{A}}$ & $6.5 \pm 1.5^{\mathrm{a}, \mathrm{AB}}$ & $7.4 \pm 0.8^{\mathrm{a}, \mathrm{C}}$ & $7.0 \pm 1.4^{\mathrm{a}, \mathrm{B}}$ \\
\hline
\end{tabular}

Means within row with different lowercase superscript letters are significantly different $(\mathrm{P}<0.05)$.

Means within column with different capital superscript letters are significantly different $(\mathrm{P}<0.05)$.

Values are mean \pm standard deviation $(\mathrm{n}=11)$.

S: potato starch; F: pea fibre; 1: $25 \%$ of fat was substituted; $2: 50 \%$ of fat was substituted; $3: 75 \%$ of fat was substituted.

Acta Alimentaria 49, 2020 
Composition of sausages significantly affected the perception of saltiness on the second week of storage. The salt content was the same for all formulations, but there were differences in the scores of saltiness. The control was assessed as being significantly saltier than low-fat sausages (Table 3). The control was also significantly juicier than sausages with starch, i.e. $\mathrm{S} 1, \mathrm{~S} 2$, and S3 on the second week of storage. Similar observations were done in a previous assay on fresh sausages (VARGA-VISI et al., 2017). Starch provided an enhanced retention of the liquid during chewing related to high-fat control. Therefore, these low-fat sausages were less juicy and were perceived less salty than the control.

As the storage time proceeded, from the second to the fourth week, the saltiness and juiciness of the control product decreased, therefore, these values of full-fat sausage became similar to those of low-fat sausages (Table 3). There were no significant differences in saltiness between the low-fat sausages and the control at the end of the storage.

\section{Conclusions}

The assays showed that Bologna turkey sausages, in which fat was partially replaced with either potato starch or pea fibre, can be stored for four weeks at $4{ }^{\circ} \mathrm{C}$ without negatively affecting microbiological quality. If the sanitary conditions of the raw materials and the processing are good, these sausages remain microbiologically stable under the studied circumstances.

Based on the instrumental colour measurements, colour fading did not occur during storage. Regarding the sensory attributes as odour, consistency, taste, and overall impact, sausages in which $25 \%$ of fat was substituted with pea fibre or potato starch were assessed as having the same quality as the control during the four-week chilled storage; while the sensory quality of sausages in which $50 \%$ or $75 \%$ of fat was substituted showed some decline.

Changes in saltiness were associated with that of juiciness, as the perception of salty taste depends on the amount of salty liquid released from sausage during mastication. Initially, low-fat sausages were assessed less salty than full-fat analogues with the same salt content. However, based on the result of present storage experiment, this phenomenon was temporary. Differences only existed at the early stage of storage. Sausages had the same saltiness at the end of the four-week storage period. The background of this observation is that initial high levels of juiciness and saltiness of the control product decreased by time, while those of lowfat products remained at the same level during the four-week storage.

This work was supported by project „EFOP-3.6.3-VEKOP-16-2017-00005” and co-funded by the European Social Fund and the Hungarian State.

\section{References}

Cáceres, E., García, M.L \& Selgas, M.D. (2008): Effect of pre-emulsified fish oil - as source of PUFA n-3 - on microstructure and sensory properties of mortadella, a Spanish Bologna-type sausage. Meat Sci., 80, $183-193$.

Colmenero, F.J., Carrascosa, A.V., Barreto, G., Fernandez, P. \& Carballo, J. (1996): Chopping temperature effects on the characteristics and chilled storage of low- and high-fat pork Bologna sausages. Meat Sci., 44, $1-9$. 
de Almeida, P.L., de Lima, S.N., Costa, L.L., De Oliveira, C.C., Damasceno, K.A., dos Santos, B.A. \& CAmpagnol, P.C. (2015): Effect of jabuticaba peel extract on lipid oxidation, microbial stability and sensory properties of Bologna-type sausages during refrigerated storage. Meat Sci., 110, 9-14.

Feng, T., Ye, R., Zhuang, H., Rong, Z., Fang, Z., Wang, Y., Gu, Z. \& Jin, Z. (2013): Physicochemical properties and sensory evaluation of Mesona Blumes gum/rice starch mixed gels as fat-substitutes in Chinese Cantonesestyle sausage. Food Res. Int., 50, 85-93.

Holley, R.A. (1997): Impact of slicing hygiene upon shelf life and distribution of spoilage bacteria in vacuum packaged cured meats. Food Microbiol., 14, 201-211.

Jiménez-Colmenero, F. \& CASSEnS, R.G. (1987): Influence of an extract of liver on colour and shelf stability of sliced bologna. Meat Sci., 21, 219-230.

EN ISO 4833:2 (2003): Microbiology of food and animal feeding stuffs. Horizontal method for the enumeration of micro-organisms.

EN ISO 6579 (2006): Microbiology of food and animal feeding stuffs. Horizontal method for the detection of Salmonella spp. (ISO 6579:2002)

EN ISO 6888-1 (2008): Microbiology of food and animal feeding stuffs. Horizontal method for the enumeration of coagulase-positive staphylococci (Staphylococcus aureus and other species).

MSZ ISO 16649-2 (2005): Élelmiszerek és takarmányok mikrobiológiája. Horizontális módszer a ß-glükuronidázpozitív Escherichia coli megszámlálására. (Microbiology of food and animal feeding stuffs. Horizontal method for the enumeration of ß-glucoronidase-positive Escherichia coli.)

MSZ ISO 21528-2 (2007): Élelmiszerek és takarmányok mikrobiológiája. Horizontális módszerek az enterobaktériumok kimutatására és számlálására. (Mikrobiology of food and animal feeding stuffs. Horizontal methods for the detection and enumeration of Enterobacteriaceae.)

Nowak, B., von Mueffling, T., Grotheer, J., Klein, G., \& Watkinson, B.M. (2007): Energy content, sensory properties, and microbiological shelf life of German Bologna-type sausages produced with citrate or phosphate and with inulin as fat replacer. J. Food Sci., 72, S629-S638.

Varga-Visi, É. \& Toxanbayeva, B. (2017): Application of fat replacers and their effect on quality of comminuted meat products with low lipid content: A review. Acta Alimentaria, 46, 181-186.

Varga-Visi, É., Toxanbayeva, B., Andrássyné BaKa, G. \& Romvári, R. (2017): Organoleptic quality of reduced fat turkey sausage using pea fibre or potato starch additives. Acta Agraria Kaposváriensis, 21, 53-59.

Varga-Visi, É., Toxanbayeva, B., Andrássyné Baka, G. \& Romvári, R. (2018): Textural properties of turkey sausage using pea fibre or potato starch as fat replacers. Acta Alimentaria, 47, 36-43.

Viuda-Martos, M., Ruiz-Navajas, Y., Fernández-López, J. \& Pérez-Álvarez, J.A. (2010): Effect of orange dietary fibre, oregano essential oil and packaging conditions on shelf-life of bologna sausages. Food Control, $21,436-443$.

Open Access statement. This is an open-access article distributed under the terms of the Creative Commons Attribution 4.0 International License (https://creativecommons.org/licenses/by/4.0/), which permits unrestricted use, distribution, and reproduction in any medium, provided the original author and source are credited, a link to the $\mathrm{CC}$ License is provided, and changes - if any - are indicated. (SID_1) 